Bailey's career has been an extraordinary one. His father was an early settler in what a century ago was the wilderness of Michigan, and the son's early years were thus associated with the primitive con. ditions of pioneer life. Following his graduation from college in 1882 he served for several years as assistant to the eminent American botanist Asa Gray at Harvard University, and it was this experience, plus his personal interests, which determined his future career. $\mathrm{He}_{\Theta}$ is the last living associate of Gray, who, in turn, was a frequent visitor to London and was the outstanding American exponent of the Darwinian hypothesis. Even when because of his special qualifications Bailey was selected as dean and director of agriculture at Cornell University in 1903, he accepted appointment only on the condition that he would be permitted to resign from administrative work at the end of ten years. $\mathrm{He}$ retired from academic work as emeritus professor of agriculture in 1921, but this did not mean quiescence on his part. His energies have since that date been devoted to his special botanical and horticultural interests, including the botany of cultivated beauty, an intensive study of North American Rubus, and a long-continued investigation of the palms and their classification; and it is this special interest in palms that has inspired him to make trip after trip to remote parts of Mexico, the West Indies and South America in recent years, with future ones already planned. In 1937 he presented his home, his library and his large herbarium to Cornell University, this unit being designated as "The Bailey Hortorium" ; and of this he is still the director. His honours have been very numerous, for the value of his achievements has been recognized all over the world. Among these is foreign membership of the Linnean Society and honorary membership of the Royal Horticultural Society of London.

\section{U.S. National Museum : Dr. A. Remington Kellogg}

Dr. A. Remingron Kelloga has been appointed director of the United States National Museum. Dr. Kellogg has been curator of mammals in the Smith. sonian Institution for the past seven years. $\mathrm{He}$ is one of the leading experts on whales and whale-like animals. His doctorate thesis, dealing with cetacean palæontology, attempted to trace the ancestry of the earth's largest animals from their land origins. He has served as delegate for the United States on several international congresses dealing with whale conservation and had a leading part in the establishment of the great Antarctic whale sanctuary set up by international agreement. The National Museum, which Dr. Kellogg now will administer, is the largest of the Federal bureaux administered by the Smith. sonian Institution. It is the storehouse of what now is probably the most extensive systematized natural history collections in the world, ranging from elephants to fossil insects. It contains large ethnological and historical collections and valuable series in the field of mechanies and inventions.

\section{University of Cambridge}

GENERAI SMUTS was installed as chancellor of the University of Cambridge on June 10. He then conferred honorary degrees on the following, among others : Mr. Winston Churchill ; Sir Stafford Cripps ; Sir Hector Hetherington, principal and vice-chancellor of the University of Glasgow; Mr. Charles Seymour, president of Yale University; Mr. J. F. Cameron, master of Gonville and Caius College, Cambridge;
Sir Hugh Lett, president of the British Medical Association; Sir Wilson Jameson, chief medical officer of the Ministries of Health and Education; Sir Richard Livingstone, vice-chancellor of the University of Oxford; Sir Robert Robinson, president of the Royal Society; Sir Paul Fildes, of the Medical Research Council ; and Mr. Arnold Toynbee, director of studies in the Royal Institute of International Affairs.

\section{National Federation of Educational Film Groups}

THE National Federation of Educational Film Groups recently held its first annual conference in King's College, University of London. Membership of the Federation now amounts to thirty-three groups, representing more than 2,500 teachers. The Federa. tion aims at co-ordinating and assisting the activities of groups of teachers specifically organised to encourage and develop the use of visual aids to teaching, at stimulating the formation and development of such groups, and at collating and analysing the views and knowledge of those experienced in visual methods. Its work includes the development of a library of film strips and charts, the publication of surveys of exist ing films under specific subject headings, and the organisation of courses for the study of visual aids. The main resolution debated at the conference welcomed the plans of the National Committee for Visual Aids and reaffirmed the support of the Federation in the Committee's task of promoting the wider adoption of visual methods in education. Attention was directed to the need for breaking the "vicious circle of supply and demand in materials", to the importance of reducing production costs, and to the necessity of ensuring that units making educational films were at all times assisted by clear directives. It was decided to establish a fact-finding committee which should report to the Council of the Federation on matters concerning the production and distribution of visual aids.

The conference was also made the occasion of an exhibition housed in the large hall of King's College and designed to provide a wide selection of equipment and materials for visual presentation. Makers, producers and distributors of visual material and projectors had been invited to exhibit and nearly fifty had accepted. The range of exhibits included film and film strip projectors, film strips, wall charts and accessories. An ingenious arrangement of stalls made for the convenience of both exhibitors and visitors and allowed demonstrations to proceed simultaneously. A useful guide-book was available containing details of exhibits and available sources of supply. A nearby room was used for full-length projection of educational films and film strips. The exhibition was well attended, and stall-holders were kept busy throughout the day. The idea of combining conference and exhibition was certainly a happy one, and the organisers are to be congratulated on this and on the excellence of their arrangements.

\section{Chemical Engineering and Fuel Technology at the University of Durham}

Commencrna in October 1948, King's College, Newcastle upon Tyne, will offer a two-year postgraduate course in chemical engineering leading to the degree of master of science in chemical engineering of the University of Durham. The course will be available to graduates in mechanical engineering or to those who possess some equivalent degree or qualification. The opportunity has been taken to 